\title{
Variation and resilience of rocky intertidal fish in western Portugal
}

\author{
Claudia Faria*, Vitor Almada \\ Unidade de Investigação em Eco-Etologia, Instituto Superior de Psicologia Aplicada, R. Jardim do Tabaco, 34, \\ P-1100 Lisboa, Portugal
}

\begin{abstract}
A monthly census of resident fishes in tide pools was made at 3 sites on the Portuguese west coast, from 1993 to 1997 . A total of 43 tide pools was monitored. Results of manipulation (addition. and removal) experiments are presented. There is a very high level of consistency in the numbers of species at 1 site. Experiments on removal and addition show that the number of fish in the pools returns to normal in a few weeks. The inter-annual fluctuations of recruitment are less pronounced as the fish grow, possibly due to density dependent mortality. At the other 2 sites, where the pools are disturbed by storms that reshape their contents and move large quantities of sand, there is a less consistent pattern. The agonistic behaviour of tide pool fishes is strongly related to the priority of access to holes and crevices and this may place limits on the number of fishes of a given size that can exist in each pool as a function of topographic complexity
\end{abstract}

KEY WORDS: Intertidal fishes - Resilience - Inter-annual variations · Fish communities

\section{INTRODUCTION}

There has been considerable debate on the mechanisms that determine population size and community structure in reef fishes (for a review see: Sale 1975, 1978, Brock et al. 1979, Doherty 1983, Jones 1987a,b). Most of these studies have focused on coral reef fishes, probably due to the ease with which fish populations can be monitored in coral reefs and also to the challenge that the high diversity of fish communities on that habitat poses to fish ecologists. In particular, this debate has centered on the relative value of 2 types of models: (1) deterministic models in which fish communities are supposed to be in equilibrium, where competition and resource limitations are the major controlling factors (Itzkowitz 1977, Brock et al. 1979, Behrents 1987, Dufour \& Galzin 1992); (2) stochastic non-equilibrium models that assume that chance events caused by the spatial and temporal fluctuations on the availability of larvae and random vacations caused by the death of juvenile or adult fishes are supposed to determine the local composition of each fish assemblage, generating conditions that would allow the coexis-

·E-mail: cfaria@ispa.pt tence of high numbers of species, each below its carrying capacity (Dale 1978, Sale 1978, Doherty 1982, 1983).

The strong fluctuations of rocky intertidal habitats would, at first sight, lead to the expectation that the fish assemblages that inhabit them would be subjected to strong stochastic disturbances, being intrinsically unstable. However, the few studies that have investigated spacio-temporal variability in rocky intertidal fish communities reveal a considerable level of stability and resilience of these communities when they are subjected to experimental disturbances (Thomson \& Lehner 1976, Larson 1980, Grossman 1982).

Connell (1985) reviewed the relative importance of larval availability and post-recruitment processes in rocky intertidal invertebrate populations, and found that in a few cases larval supply may limit population size for some species, but in many others, larval supply is more than sufficient to ensure population renewal. In this situation, the predominant mechanism that limits population size is density dependent postrecruitment mortality.

In this paper we present data on the spatio-temporal variation of resident rocky intertidal fishes in tide pools, located on the west coast of Portugal. 


\section{MATERIAL AND METHODS}

The study period ranged from January 1993 to December 1997. Three monitoring sites were established on the Portuguese west coast at Avencas (Site 1) $\left(38^{\circ} 41^{\prime} \mathrm{N}, 9^{\circ} 22^{\prime} \mathrm{W}\right), \mathrm{S}$. Pedro do Estoril (Site 2) $\left(38^{\circ} 41^{\prime} \mathrm{N}, 9^{\circ} 22^{\prime} \mathrm{W}\right)$ and St. Cruz (Site 3) (38 $56^{\prime} \mathrm{N}$, $9^{\circ} 27^{\prime} \mathrm{W}$ ). The first 2 sites are less than $1 \mathrm{~km}$ apart but were treated separately because they differ markedly in their level of disturbance. Both are located in moderately exposed shores (sensu Lewis 1978), but while at Site 1 the tide pools are located on extensive rocky platforms that reduce the impact of waves, those at Site 2 are less protected and are near a sandy beach. Winter storms in this last locality cause wide variations in the topography of tide pools, due to the movement of boulders and large quantities of sand, in and out of the pools. While the 2 above mentioned stations face southwest and are protected from waves for most of the year, Site 3 faces west and is subjected to strong wave action all year round.

At each station, a number of tide pools located in the mid-intertidal were selected. A summary of tide pool characteristics is given in Table 1. A total of 43 tide pools (11 at Site 1,16 pools at Site 2 and 16 pools at Site 3) was monitored. The pools at Site 1 and Site 2 were inspected monthly from January 1993 to December 1997, and those at Site 3 were visited monthly from June 1995 to June 1996 and at 2 monthly intervals in the remaining period.

During each inspection, all the fishes that could be located in the pool were collected with a hand net. Their species, sex (when possible) and total length (TL) were recorded. All fishes were kept in a bucket with sea-water until collecting was completed, and were subsequently returned to the same pool. Since the fishes tended to hide in crevices, holes and under stones when disturbed, each census was composed of several visits to the pool, separated by periods of several minutes, during which other pools were visited. This allowed the fishes to come out of their hiding places. All the stones present were removed to facilitate collection, and were replaced in the same position after the pool was censused. A census was considered complete after a visit in which no fishes were seen, despite intensive probing in holes and crevices.

Table 1. Tide pool characteristics at each study site

\begin{tabular}{|lrrrr|}
\hline \multirow{2}{*}{ Study area } & \multicolumn{2}{c}{ Area $\left(\mathrm{cm}^{2}\right)$} & \multicolumn{2}{c|}{ Depth $(\mathrm{cm})$} \\
& Mean & SD & Mean & SD \\
\hline Site $1(n=11)$ & 1465.46 & 1026.81 & 23.18 & 8.62 \\
Site $2(n=16)$ & 2763.75 & 4138.18 & 17.06 & 8.79 \\
Site 3 $(n=16)$ & 10668.88 & 9577.61 & 21.31 & 9.36 \\
\hline
\end{tabular}

No anesthetic was used for 2 reasons: (1) since the pools have large water volumes, it was not feasible to refill them with clean water after collection. This would mean that the fishes would continue to be exposed to anesthetic until the rising tide began to flush the pools; (2) tests have been made of the results of collections with and without the anesthetic Quinaldine in another set of pools. No significant differences between the distributions of fish sizes in samples collected with and without the anesthetic were found (KolmogorovSmirnov 2 sample tests: February-[Lipophrys pholis] $\mathrm{DN}=0.375, \mathrm{p}>0.05, \mathrm{n}_{\text {with }}=64, \mathrm{n}_{\text {without }}=35 \mathrm{i}$ [Coryphoblennius galerita] $\mathrm{DN}=0.333, \mathrm{p}>0.05, \mathrm{n}_{\mathrm{with}}=123$, $\mathrm{n}_{\text {without }}=91$; July- $[$ L. pholis $] \mathrm{DN}=0.333, \mathrm{p}>0.05, \mathrm{n}_{\text {with }}$ $=40, \mathrm{n}_{\text {without }}=32 ;[$ C. galerita $] \mathrm{DN}=0.332, \mathrm{p}>0.05$, $n_{\text {with }}=78, n_{\text {without }}=70$ ), nor between fish abundances (Wilcoxon test $[\mathrm{n}=8$ ]: February-[Lipophrys pholis] $Z=1.19, \mathrm{p}>0.05$; [Coryphoblennius galerita] $Z=2.20$, $\mathrm{p}<0.05$; July- $[$ L. pholis $] Z=1.83, \mathrm{p}>0.05$; $[C$. galerita] $Z=1.83, \mathrm{p}>0.05$ ), except for $C$. galerita in the winter, when the fishes are less active. In addition, there were highly significant correlations between the numbers of fishes of each species collected by the 2 methods (Spearman rank correlation $[\mathrm{n}=8]$ : February- $\left[\right.$ L. pholis] $\mathrm{r}_{\mathrm{s}}=0.691, \mathrm{p}>0.05$; [C. galerita] $\mathrm{r}_{\mathrm{s}}=0.368, \mathrm{p}>0.05$, July- $[$ L. pholis $] \mathrm{r}_{\mathrm{s}}=0.841, \mathrm{p}<0.05$; [C. galerita] $r_{\mathrm{s}}=0.994, \mathrm{p}<0.01$ ), except for $C$. galerita in the winter. The proportion of fishes collected without anesthetic, taking the anesthetic sample as unity, ranged from 0.67 in winter to 0.86 in summer (data from 8 pools).

Removal and addition experiments involved 3 additional sets of pools, at Site 1 and Site 2 ( 8 control pools, 8 removal pools, from which fishes were removed, and 8 addition pools, to which fishes were added). In control pools, all the fishes that could be collected were marked by cutting specific rays of the dorsal fin before release. In removal pools, the fishes were also marked but were returned to tide pools more than $500 \mathrm{~m}$ away. These pools (addition pools), that received the fishes removed from the removed pools, had been previously censused in the same lowtide. All 3 sets of pools were re-censused after 15 and $30 \mathrm{~d}$ after the manipulation. This procedure was performed in May/June and November/December of 1995 , 1996 and 1997

Statistical analysis was performed using the computer program Statistica for Windows (ver. 4.5, C. Statsoft Inc. 1993).

\section{RESULTS}

The most common resident (i.e. fishes which after settlement live and breed in the intertidal zone sensu 
Gibson 1982) intertidal fishes in the study area are Lipophrys pholis (Linnaeus, 1758) and Coryphoblennius galerita (Linnaeus, 1758), and in some habitats Gobius cobitis (Pallas, 1811), Gobius paganellus (Linnaeus, 1758) and Lepadogaster lepadogaster purpurea (Bonnaterre, 1788).

The present study concentrates on the shanny Lipophrys pholis, the Montagu's blenny Coryphoblennius galcrita and the giant goby Gobius cobitis, the most common species in tide pools.

For each year we computed the average number of fishes of each species at each pool, by adding the numbers found during each visit divided by the number of visits. In Table 2 we present the values of the Kendall coefficient of concordance $(W)$ for the study period, for each species and study site. Data on adult Gobius cobitis are not presented for Site 1 and Site 2 because they were very uncommon in tide pools. The same applies for both juveniles and adults of this species at Site 3.

The most striking feature of Table 2 is the high level of congruence between years in Site 1 , the most stable of the 3 sites. However, even for Site 2 and Site 3 the values of $W$, which reflect the average rank correlation between consecutive pairs of years, are quite high. This conclusion applies for each species separately and for the total of the 3 species summed. This finding means that in each study site, each pool tended to show a consistent rank in the abundance of each fish category (juveniles or adults), which varied little from year to year during the study period.

Table 2. Kendall coefficient of concordance $(W)$ for each species and study site (for all species: juveniles $=$ fishes $<3 \mathrm{~cm}$ TL Lipophrys pholis adults $=$ fishes $>6 \mathrm{~cm} \mathrm{TL}$; Coryphoblemmius galerita adults $=$ fishes $>3 \mathrm{~cm} \mathrm{TL}$ ). Data from 1993 to 1997 at Site 1 and Site 2 and 1994 to 1997 at Site 3

\begin{tabular}{|c|c|c|c|}
\hline Study area & Species / category & $W$ & $\mathrm{p}$ \\
\hline \multirow{5}{*}{$\begin{array}{l}\text { Site } 1 \\
(\mathrm{n}=11, \mathrm{df}=4)\end{array}$} & L. pholis: & 0.830 & $<0.001$ \\
\hline & adults & 0.863 & $<0.001$ \\
\hline & C. galerita: juveniles & 0.854 & $<0.001$ \\
\hline & $\begin{array}{l}\text { adults } \\
\text { juveniles }\end{array}$ & $\begin{array}{l}0.859 \\
0.903\end{array}$ & $\begin{array}{l}<0.001 \\
<0.001\end{array}$ \\
\hline & Total number of fishes & 0.947 & $<0.001$ \\
\hline \multirow{6}{*}{$\begin{array}{l}\text { Site } 2 \\
(\mathrm{n}=16, \mathrm{df}=4)\end{array}$} & L. pholis: & 0.617 & $<0.001$ \\
\hline & adults & 0.686 & $<0.001$ \\
\hline & C. galerita: juveniles & 0.602 & $<0.001$ \\
\hline & adults & 0.745 & $<0.001$ \\
\hline & G. cobitis: juveniles & 0.761 & $<0.001$ \\
\hline & Total number of fishes & 0.820 & $<0.001$ \\
\hline \multirow{5}{*}{$\begin{array}{l}\text { Site } 3 \\
(\mathrm{n}=16, \mathrm{df}=3)\end{array}$} & juveniles & 0.743 & $<0.001$ \\
\hline & adults & 0.427 & $<0.001$ \\
\hline & C. galerita: juveniles & 0.601 & $<0.001$ \\
\hline & adult & 0.698 & $<0.001$ \\
\hline & Total number of fishes & 0.783 & $<0.001$ \\
\hline
\end{tabular}

Table 3. Friedman 2-way analysis of variance for each species and study site (for all species: juveniles $=$ fishes $<3 \mathrm{~cm} \mathrm{TL}$; Lipophrys pholis adults $=$ fishes $>6 \mathrm{~cm} \mathrm{TL}$ Coryphoblemmius galerita adults $=$ fishes $>3 \mathrm{~cm} \mathrm{TL}$ ). Data from 1993 to 1997 at Site 1 and Site 2 and 1994 to 1997 at Site 3

\begin{tabular}{|c|c|c|c|}
\hline Study area & Species / category & $\chi^{2}$ & $\mathrm{p}$ \\
\hline \multirow[t]{4}{*}{$\begin{array}{l}\text { Site } 1 \\
(\mathrm{n}=11, \mathrm{df}=4)\end{array}$} & $\begin{array}{ll}\text { L. pholis: } & \begin{array}{l}\text { juveniles } \\
\text { adults }\end{array}\end{array}$ & $\begin{array}{r}15.194 \\
5.323\end{array}$ & $\begin{array}{c}<0.01 \\
\text { ns }\end{array}$ \\
\hline & C. galerita: juveniles & 14.545 & $<0.01$ \\
\hline & $\begin{array}{ll} & \text { adults } \\
\text { G. cobitis: } & \text { juveniles }\end{array}$ & $\begin{array}{r}5.701 \\
12.636\end{array}$ & $\begin{array}{c}\text { ns } \\
<0.05\end{array}$ \\
\hline & Total number of fishes & 17.721 & $<0.01$ \\
\hline \multirow[t]{4}{*}{$\begin{array}{l}\text { Site } 2 \\
(\mathrm{n}=16, \mathrm{df}=4)\end{array}$} & $\begin{array}{ll}\text { L. pholis: } & \text { juveniles } \\
\text { adults }\end{array}$ & $\begin{array}{r}24.862 \\
2.803\end{array}$ & $\begin{array}{c}<0.001 \\
\text { ns }\end{array}$ \\
\hline & $\begin{array}{c}\text { C. galerita: juveniles } \\
\text { adults }\end{array}$ & $\begin{array}{r}22.727 \\
9.870\end{array}$ & $\begin{array}{c}<0.001 \\
\text { ns }\end{array}$ \\
\hline & G. cobitis: juveniles & 17.206 & $<0.05$ \\
\hline & Total number of fishes & 21.734 & $<0.001$ \\
\hline \multirow[t]{3}{*}{$\begin{array}{l}\text { Site 3 } \\
(\mathrm{n}=16, \mathrm{df}=3)\end{array}$} & juveniles & 21.336 & $<0.001$ \\
\hline & $\begin{aligned} \text { C. galerita: juveniles } \\
\text { adults }\end{aligned}$ & $\begin{array}{r}30.616 \\
5.942\end{array}$ & $\begin{array}{c}<0.001 \\
\text { ns }\end{array}$ \\
\hline & Total number of fishes & 32.582 & $<0.001$ \\
\hline
\end{tabular}

It could be argued that the finding that each pool can be categorized by a given rank of fish abundance from year to year, reflects only its relative suitability for each fish category in comparison with other pools, and not a true stability of absolute numbers of fishes. To test this hypothesis a Friedman 2-way analysis of variance was performed for each study site and fish category. The results are presented in Table 3 .

The results indicate that the numbers of adult fish did not differ significantly along the study period, while the numbers of juveniles showed significant fluctuations. This result points to a greater stability in the numbers of adults when compared to juveniles (see Fig. 1). Indeed, when we compared the ratio between the values of abundance between the years with the highest and lowest numbers of fishes for each category, we find that while for juveniles they can reach a value of 3.9 , those of adults are only around 2 .

In addition, although the data are still too few to reach firm statistical conclusions, the available evidence suggests that survival rate is negatively correlated with juvenile recruitment (Table 4).

To assess the resilience of the fish assemblages present in the pools, removal and addition experiments were performed as described in 'Material and methods'. For each experimental and control pool, the number of fishes for each species prior to the manipulation and the number found $2 \mathrm{wk}$ and $30 \mathrm{~d}$ after were compared (Table 5). The net gain or loss of fishes for that period was computed. The results are summarized in Table 6. 


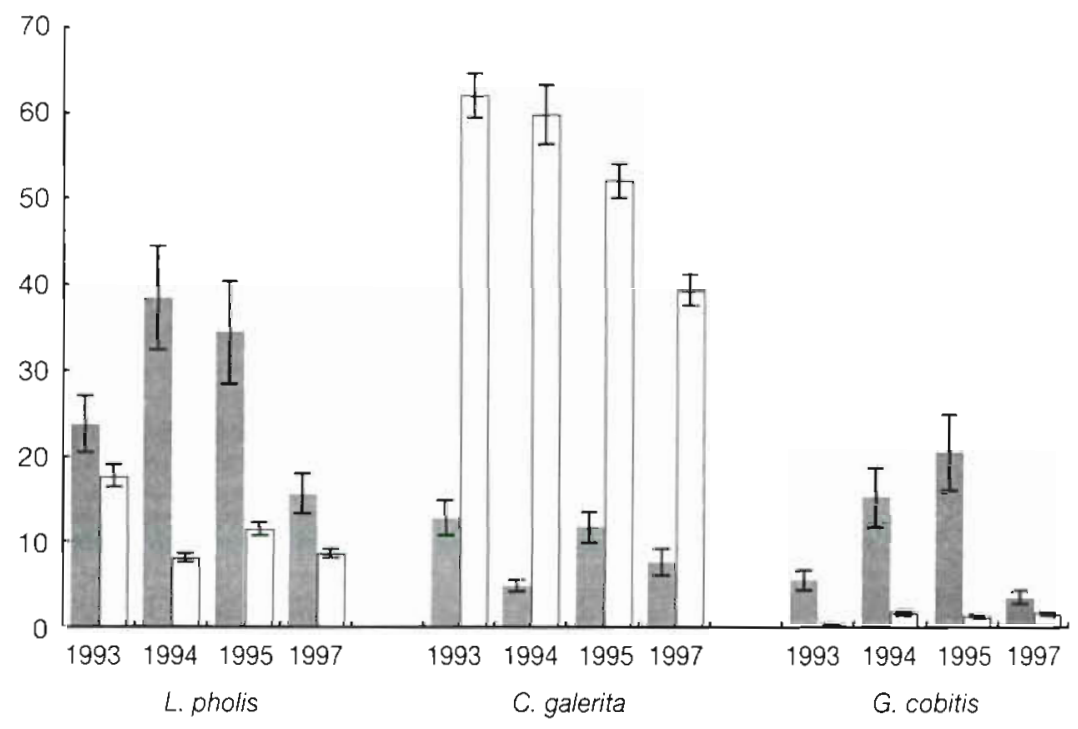

Fig. 1. Annual mean and standard error of monthly counts of juveniles (grey bars) and adults (white bars) of each species, observed in 27 tide pools of Site 1 and Site 2, during monthly samples in 1993, 1994, 1995 and 1997 (for all species: juveniles $=$ fishes $<3 \mathrm{~cm}$ TL; Lipophrys pholis and Gobius cobitis adults $=$ fishes $>6 \mathrm{~cm}$ $\mathrm{TL}_{\mathrm{i}}$ Coryphoblemmius galerita adults $=$ fishes $>3 \mathrm{~cm} \mathrm{TL}$ ). Data from Site 3 was not presented because of the lack of monthly inspections. The same applies to data from 1996 at Site 1 and Site 2
During the first 2 wk after experimental manipulation, the addition pools tend to loose fish when compared with the control pools, while the removal pools tend to gain fishes when compared with controls. Apparently, the return to values similar to those prior to disturbance occurred after Day 15, as indicated by the lack of significant differences between data collected $15 \mathrm{~d}$ and $30 \mathrm{~d}$ after the start of the experiments, except in a single case (November/December 1995) for reasons unclear to us.

Kolmogorov-Smirnov 2 sample tests performed on the distribution of fish sizes (class sizes differing by $1 \mathrm{~cm}$ TL), before and after the experiments did not reveal any significant difference for any fish species. Thus not only the pools tend to return to numbers similar to those prior to the experiments, but the size distribution tends also to be restored.

Table 4. Number of juveniles ( $<3 \mathrm{~cm}$ TL) present in tide pools and survival rate of each species (for Lipophrys pholis and Gobius cobitis we considered the rate betwenn the total number of fishes with $6 \mathrm{~cm}$. TL and the number of juveniles present in pools in each year; for Coryphoblemmius galerita we considered the rate between the total number of fishes with $3 \mathrm{~cm}$ TL and the number of juveniles present in pools in each year). The year of 1996 was not considered because we had only data from July to December

\begin{tabular}{|c|c|c|c|c|c|c|}
\hline & \multicolumn{2}{|c|}{ L. pholis } & \multicolumn{2}{|c|}{ C. galerita } & \multicolumn{2}{|c|}{ G. cobitis } \\
\hline & Juveniles & Survival rate & Juveniles & Survival rate & Juveniles & Survival rate \\
\hline 1993 & 62 & 0.98 & 57 & 0.56 & 31 & 0.23 \\
\hline 1994 & 135 & 0.31 & 19 & 0.84 & 89 & 0.13 \\
\hline 1995 & 139 & 0.16 & 42 & 0.57 & 128 & 0.06 \\
\hline 1997 & 68 & 0.48 & 32 & 0.62 & 1.8 & 0.83 \\
\hline
\end{tabular}

Table 5. Net gain (+) and loss (-) of fishes summed for each group of pools (control, removal and addition), for each removal and addition experiment. (1) 0-15 d interval; (2) 15-30 d interval

\begin{tabular}{|c|c|c|c|c|c|c|c|c|c|c|c|c|}
\hline & \multicolumn{4}{|c|}{1995} & \multicolumn{4}{|c|}{1996} & \multicolumn{4}{|c|}{1997} \\
\hline & \multicolumn{2}{|c|}{ May/Jun } & \multicolumn{2}{|c|}{ Nov/Dec } & \multicolumn{2}{|c|}{ May/Jun } & \multicolumn{2}{|c|}{ Nov/Dec } & \multicolumn{2}{|c|}{ May/Jun } & \multicolumn{2}{|c|}{ Nov/Dec } \\
\hline & 1 & 2 & 1. & 2 & 1 & 2 & 1 & 2 & 1 & 2 & 1 & 2 \\
\hline \multicolumn{13}{|l|}{ Control } \\
\hline L. pholis & +11 & +29 & +2 & -7 & -8 & -9 & +12 & -22 & -1.7 & -11 & -16 & -1.4 \\
\hline C. galerita & -9 & -8 & -5 & +10 & -16 & -15 & -9 & -24 & +3 & -4 & +1 & -6 \\
\hline Total number of fishes & +10 & +42 & -17 & -9 & -22 & -16 & +4 & -51 & -28 & -47 & -25 & -29 \\
\hline \multicolumn{13}{|l|}{ Removal } \\
\hline L. pholis & +40 & +84 & +13 & +13 & +16 & +29 & +9 & +11 & +15 & +10 & +17 & +15 \\
\hline C. galerita & +32 & +42 & +18 & +18 & +17 & +9 & +15 & +6 & +9 & +3 & +18 & +16 \\
\hline Total number of fishes & +97 & +150 & +35 & +36 & +26 & +45 & +29 & +18 & +29 & +25 & +39 & +31 \\
\hline \multicolumn{13}{|l|}{ Addition } \\
\hline L. pholis & -21 & +10 & -47 & -70 & -46 & -39 & -147 & -20 & -147 & -147 & -49 & -10 \\
\hline C. galerita & -50 & -55 & -75 & -76 & -31 & -18 & -36 & -78 & -36 & -39 & -101 & -60 \\
\hline Total number of fishes & -77 & -45 & -128 & -62 & -81 & -46 & -195 & -104 & -195 & -197 & -129 & -80 \\
\hline
\end{tabular}


Table 6. Kruskall-Wallis analysis of variance between the number of fishes for each species prior to the manipulation and that found $15 \mathrm{~d}$ after and $30 \mathrm{~d}$ after, in 8 control pools, 8 addition pools and 8 removal pools. "All pairs of data showed significant differences (Dunn's test)

\begin{tabular}{|c|c|c|c|c|c|c|}
\hline \multirow{2}{*}{$\frac{\text { Year }}{1995}$} & \multirow{2}{*}{$\begin{array}{l}\text { Period } \\
\text { May/Jun }\end{array}$} & \multirow{4}{*}{$\begin{array}{l}\text { Species } \\
\text { L. pholis } \\
\text { C. galerita } \\
\text { Total number of fishes }\end{array}$} & \multicolumn{2}{|c|}{$\begin{array}{l}0-15 \text { d interval } \\
H(2, \mathrm{n}=24) \mathrm{p}\end{array}$} & \multicolumn{2}{|c|}{$\begin{array}{l}15-30 \text { d interval } \\
H(2, \mathrm{n}=24) \mathrm{p}\end{array}$} \\
\hline & & & 9.239 & $<0.05\left({ }^{\circ}\right)$ & 2.040 & ns \\
\hline & & & 13.625 & $\left.<0.011^{\circ}\right)$ & 3.405 & ns \\
\hline & & & 13.127 & $<0.01\left(^{\circ}\right)$ & 0.167 & ns \\
\hline & Nov/Dec & L. pholis & 8.975 & $<0.05\left({ }^{\circ}\right)$ & 6.875 & $<0.05\left({ }^{\circ}\right)$ \\
\hline & & C. galerita & 13.431 & $\left.<0.011^{\circ}\right)$ & 8.106 & $<0.05$ \\
\hline & & Total number of fishes & 16.521 & $<0.001\left({ }^{\circ}\right)$ & 9.232 & $<0.05\left({ }^{\circ}\right)$ \\
\hline \multirow[t]{6}{*}{1996} & May/Jun & L. pholis & 8.546 & $<0.05\left(^{\circ}\right)$ & 2.837 & ns \\
\hline & & C. galerita & 13.289 & $\left.<0.01 i^{\circ}\right)$ & 0.143 & ns \\
\hline & & Total number of fishes & 15.589 & $<0.001\left(^{\circ}\right)$ & 2.037 & ns \\
\hline & Nov/Dec & L. pholis & 6.842 & $<0.05\left(^{\circ}\right)$ & 3.905 & ns \\
\hline & & C. galerita & 8.297 & $\left.<0.05()^{\circ}\right)$ & 6.067 & ns \\
\hline & & Total number of fishes & 10.875 & $\left.<0.011^{\circ}\right)$ & 5.363 & ns \\
\hline \multirow[t]{6}{*}{1997} & May/Jun & L. pholis & 20.614 & $\left.<0.001()^{\circ}\right)$ & 0.641 & ns \\
\hline & & C. galerita & 9.204 & $<0.05\left({ }^{\circ}\right)$ & 6.067 & ns \\
\hline & & Total number of fishes & 19.063 & $<0.001(\bullet)$ & 1.001 & ns \\
\hline & Nov/Dec & L. pholis & 10.706 & $<0.05\left({ }^{\circ}\right)$ & 0.949 & ns \\
\hline & & C. galerita & 12.753 & $<0.01\left(^{\circ}\right)$ & 0.001 & ns \\
\hline & & Total number of fishes & 12.553 & $<0.01\left({ }^{\circ}\right)$ & 1.023 & ns \\
\hline
\end{tabular}

Resident rocky intertidal fishes of many different families characteristically show parental care, and the eggs are protected and thus keep inshore until hatching of feeding larvae (Gibson 1969, 1970, 1982). Furthermore, there is some evidence that even the larrac of scroral spccics possess behavioural mechanisms that allow them to avoid dispersal, and remain near shore (Marliave 1986). Thus, it is likely that in most cases, larval supply is sufficiently high to ensure an excess of recruits and that density dependent mortality plays a major role as a determinant of population size in rocky intertidal fishes.

This stability of fish numbers is probably further reinforced by the fact that most rocky intertidal fishes live and spawn for several years (Qasim 1956, Gibson 1970 , Milton 1983, Faria et al. 1996, Gil

The results obtained in May/June are particularly interesting because they were collected in a period of very strong recruitment of juveniles that could blur the differences between experimental and control pools

\section{DISCUSSION}

The evidence strongly suggests that post-recruitment density dependent mechanisms control the numbers of fish found in tide pools and that these mechanisms are basically deterministic. This conclusion seems to be justified for the 3 species studied and is particularly strong in the case of Site 1. This is the most stable of the 3 places in terms of the variation in the amount of sand and boulders in the pools, which affect pool topography.

In an assessment of the relative importance of settlement and post-recruitment mortality as determinants of abundance of sessile invertebrates of rocky intertidal habitats, Connell (1985) found that the results of different studies follow 2 main categories: cases of high recruitment where the most important controls of population size occur after recruitment, and others, apparently less common, where larval supply seems to be the limiting factor. The studies with rocky intertidal fishes, namely those cited in the 'Introduction' and our own, seem to fall in the first category. et al. 1997), and, at least in warm waters, have protracted breeding seasons with multiple spawnings (Lee \& Chang 1977, Miller 1984, Almada et al. 1990, 1994, Faria \& Almada 1995, Almada et al. 1996, Faria et al. 1996)

This means that even if during a given period larval mortality in the plankton is high, there are many more opportunities in the same breeding season where more favorable recruitment could occur.

This situation of apparent high stability contrasts sharply with data published for marine pelagic fishes, where abundance is strongly affected by year class strength and can show variations that span more than 2 orders of magnitude (Wootton 1990). It is important to note, however, that many pelagic fish data involve heavily fished commercial species of high latitude, which often have fairly restricted breeding seasons, and are much more dependent on larval survival, while the data for intertidal fishes that we could find refer mostly to subtropical or warm temperate species.

Another interesting feature that emerged from this study was the strong resilience of the assemblages, as shown by the addition and removal experiments. Recolonization of the defaunated pools resulted from the movements of fishes of all sizes, and not only from newly settled juveniles.

A few individuals that we recaptured in the original pool had been released more than $500 \mathrm{~m}$ away, which gives an indication of the potential range of their movements. This mobility of benthic fishes contrasts 
with data published for coral reef equivalents, whose movements are often restricted to a single coral head or a fairly restricted area (Barlow 1984, Thresher 1984).

It is possible that, in general, fewer fish predators are found in the rocky intertidal zone than in coral reefs (Gibson 1988), allowing for greater fish mobility, but simple scale effects can not be ruled out. While many coral reef studies involve patch reefs that are separated by deeper channels, our study sites were composed of large rock platforms that extended for hundreds of metres without important barriers, which would limit the movements of small benthic fishes. It would be interesting to perform similar studies on small rock outcrops and in rock pools isolated, for instance in large sandy areas.

A final question refers to the possible nature of postrecruitment causes of mortality. Food resources are not necessarily limiting if you consider the extreme abundance of invertebrate prey food, when compared to fish numbers. Other studies (Connell \& Jones 1991, Faria et al. 1998a) show that topographic complexity of tide pool habitats is a major controlling factor affecting survival of juveniles and their numbers.

The great majority of rocky intertidal resident fishes from our study area, although not being territorial except for the breeding males, show well-developed agonistic behaviour repertoires in juveniles and adults of both sexes (Gibson 1968, Almada et al. 1983 Gonçalves et al. 1996, Faria et al. 1998b).

A feature typical of the agonistic interactions of these fishes is the establishment of some kind of order in the 'right of priority' of access to shelter and resting sites, already noted by Almada et al. (1983), and previously by Gibson (1968), who called it 'diffuse territoriality'. The operation of a mechanism of this type will tend to evict from the pools fishes that are not able to find shelter and resting sites most of the time, or force them to more vulnerable locations in the pools. This could provide a mechanism that would explain why topographic complexity would determine some sort of carrying capacity that is not necessarily related to the food base available. Behrents (1987) had previously shown that for the goby Lythrypnus dalli Gilbert shelter availability limits fish densities and affects mortality rates.

We suggest that further studies along these lines may provide a better understanding of rocky intertidal fish communities.

Acknowledgements. Part of this study was supported by Junta Nacional de Investigação Científica e Tecnológica (JNICT) as part of the projects PBIC/1313/MAR/92 and PRAXIS/3/3.2/EMG/1957/95 and the Pluriannual Program (UI\&D 331/94). C.F. was also supported by a grant from JNICT (PRAXIS XXI/BD/5666/95). We also would like to thank C. Silva and V. Carvalho who helped in the field work.

\section{LITERATURE CITED}

Almada VC, Dores J, Pinheiro A, Pinheiro $M$, Santos RS (1983) Contribuiçāo para o estudo do comportamento de Coryphoblennius galerita (L.) (Pisces, Blenniidae). Mem Mus Mar Ser Zool 2:1-165

Almada VC, Barata EN, Gonçalves EJ, Oliveira RF (1990) On the breeding season of Lipophrys pholis (Pisces: Blenniidae) at Arrábida, Portugal. J Mar Biol Assoc UK 70: 913-916

Almada VC, Gonçalves EJ, Santos AJ, Baptista MC (1994) Breeding ecology and nest aggregations in a population of Salaria pavo (Pisces: Blenniidae) in an area where nest sites are very scarce. J Fish Biol 45:819-830

Almada VC, Carreiro H, Faria C, Gonçalves EJ (1996) The breeding season of Coryphoblennius galerita in Portuguese waters. J Fish Biol 48:295-297

Barlow GW (1984) Patterns of monogamy among teleost fishes. Arch Fisch Wiss 35:75-123

Behrents KC (1987) The influence of shelter availability on recruitment and early juvenile survivorship of Lythrypnus dalli Gilbert (Pisces: Gobiidae). J Exp Mar Biol Ecol 107: $45-59$

Brock RE, Lewis C, Wass RC (1979) Stability and structure of a fish community on a coral patch reef in Hawaii. Mar Biol $54: 281-292$

Connell JH (1985) The consequences of variation in initial settlement vs, post-settlement mortality in rocky intertidal communities. J Exp Mar Biol Ecol 93:11-45

Connell SD, Jones GP (1991) The influence of habitat complexity on post-recruitment processes in a temperate reef fish population. J Exp Mar Biol Ecol 151:271-294

Dale G (1978) Money-in-the-bank: a model for coral. reef fish coexistence. Environ Biol Fish 3(1):103-108

Doherty PJ (1982) Some effects of density on the juveniles of two species of tropical, territorial damselfish. J Exp Mar Biol Ecol 65:249-261

Doherty PJ (1983) Tropical territorial damselfishes: is density limited by aggression or recruitment? Ecology 64(1): $176-190$

Dufour V, Galzin R (1992) Le recrutement des poissons recifaux sur l'ile de Moorea, Polynésie Française. Impact. sur la dynamique des populations et conséquences sur la. gestion des stocks. Cybium 16(4):267-277

Faria C, Almada VC (1995) Some aspects of the breeding ecology of Gobius cobitis Pallas and Gobius paganellus L. in the west coast of Portugal. Arq Mus Bocage Nova Ser II $(29): 463-471$

Faria C, Almada VC, Gonçalves EJ (1996) Juvenile recruitment, growth and maturation of Lipophrys pholis (Pisces Blenniidae), from the west coast of Portugal. J Fish Biol 49:727-730

Faria C, Almada V, Nunes MC (1998a) Patterns of agonistic behaviour, shelter occupation and habitat preference in juvenile Lipophrys pholis, Coryphoblennius galerita and Gobius cobitis. J Fish Biol 53(6):1263-1273

Faria C, Almada VC, Gonçalves EJ, Gil MF, Baptista C, Carreiro $\mathrm{H}$ (1998b) Notes on the social behaviour of Gobius cobitis (Pisces, Gobiidae). Acta Ethologica 1(1-2):49-56

Gibson RN (1968) The agonistic behaviour of juvenile Blennius pholis L. (Teleostei). Behaviour 30:192-217

Gibson RN (1969) The biology and behaviour of littoral fishes. Oceanogr Mar Biol Annu Rev 7:367-410

Gibson RN (1970) Observations on the biology of the giant goby Gobius cobitis Pallas. J Fish. Biol 2:281-288

Gibson RN (1982) Recent studies on the biology of intertidal fishes. Oceanogr Mar Biol Annu Rev 20:363-414 
Gibson RN (1988) Patterns of movement in intertidal fishes. In: Chelazzi G, Vannini M (eds) Behavioural adaptations to intertidal life. Kluwer Academic Publishers, Dordrecht, p 55-63

Gil MF, Gonçalves EJ, Faria C, Almada VC, Baptista C, Carreiro H (1997) Embryonic and larval development of the giant goby Gobius cobitis (Pisces: Gobiidae). J Nat Hist 31:799-804

Gonçalves EJ, Almada VC, Oliveira RF, Santos AJ (1996) Female mimicry as a mating tactic in males of the blenniud fish Salaria pavo. J Mar Biol Assoc UK 76:529-538

Grossman GD (1982) Dynamics and organization of a rocky intertidal fish assemblage: the persistence and resilience of taxocene structure. Am Nat 119(5):611-637

Itzkowitz $M$ (1977) Spatial organization of the Jamaican damselfish community. J Exp Mar Biol Ecol 28:217-241

Jones GP (1987a) Some interactions between residents and recruits in two coral reef fishes. J Exp Mar Biol Ecol 114: $169-182$

Jones GP (1987b) Competitive interactions among adults and juveniles in a coral reef fish. Ecology 68(5):1534-1547

Larson RJ (1980) Territorial behavior of the black and yellow rockfish and gopher rockfish (Scorpaenidae, Sebastes). Mar Biol 58:111-122

Lee SC, Chang KH (1977) Food and reproduction of the

Editorial responsibility: Otto Kinne (Editor),

Oldendorf/Luhe, Germany blenny Halmablennius Lineatus (Valenciennes). Bull Inst Zool Acad Sin 16:1-7

Lewis JR (1978) The ecology of rocky shores. Hodder and Stoughton, London

Marliave JB (1986) Lack of planktonic dispersal of rocky intertidal fish larvae. Trans Am Fish Soc 115:149-154

Miller PJ (1984) The tokology of gobioid fishes. In: Potts GW, Wootton RJ (eds) Fish reproduction: strategies and tactics Academic Press, London, p 119-154

Milton P (1983) Biology of littoral blenniid fishes on the coast of south-west England. I Mar Rinl Accor ITK 51.247-265

Qasim S (1956) The spawning habits and embryonic development of the shanny (Blennius pholis). Proc Zool Soc Lond 127:144-155

Sale PF (1975) Patterns of use of space in a guild of territorial reef fishes. Mar Biol 29:89-97

Sale PF (1978) Coexistence of coral reef fishes-a lottery for living space. Environ Biol Fish 3(1):85-102

Thomson DA, Lehner CE (1976) Resilience of a rocky intertidal fish community in a physically unstable environment. J Exp Mar Biol Ecol 22:1-29

Thresher RE (1984) Reproduction in reef fishes. NJ: THF Publications, Neptune City

Wootton RJ (1990) Ecology of teleost fishes. Chapman \& Hall, London

Submitted: November 17, 1998; Accepted: February 4, 1999

Proofs received from author(s): July 14, 1999 